Emir. J. Food Agric. 2009. 21 (1): 01-09

http://cfa.uaeu.ac.ae/ejfa.shtml

\title{
Phenological and yield characteristics of sesame (Sesamum indicum L.) as affected by nitrogen and phosphorous rates in Mubi, Northern Guinea Savanna Ecological Zone of Nigeria
}

\author{
M. A. Muhamman ${ }^{1}$, D. T. Gungula ${ }^{2}$ and A. A. Sajo ${ }^{2}$ \\ ${ }^{1}$ Department of Crop Science, Adamawa State University, Mubi, Adamawa State, Nigeria; \\ ${ }^{2}$ Department of Crop Production and Horticulture, Federal University of Technology, Yola, \\ Adamawa State, Nigeria
}

\begin{abstract}
Field experiments were conducted during the 2005 and 2006 cropping seasons at the Teaching and Research Farm of Adamawa State University, Mubi, Nigeria $\left(10^{0} 15^{\prime} \mathrm{N}, 13^{0} 16^{\prime} \mathrm{E}\right.$ and $696 \mathrm{~m}$ above sea level) to study the effect of nitrogen (N) and phosphorous (P) rates on some phenological and yield characteristics of sesame. The treatments consisted of four $\mathrm{N}$ rates: 0,30 , 60 and $90 \mathrm{~kg} \mathrm{ha}^{-1}$ and four $\mathrm{P}$ rates: $0,15,30$ and $45 \mathrm{~kg} \mathrm{ha}^{-1}$. These treatments in factorial combinations were laid out in split plot design with $\mathrm{N}$ rates assigned to main plots and $\mathrm{P}$ rates assigned to sub plots and were replicated four times. The following data were collected on phenological and yield characteristics: days to $50 \%$ flowering, days to $50 \%$ maturity, weight of biomass at eight weeks after sowing (WAS) and at harvest, dry weight of leaves at 8 WAS and at harvest, number of pods per plant and total seed yield. Results showed significant $(\mathrm{P} \leq 0.05)$ effect on all characteristics, except number of leaves at 8 WAS and days to $50 \%$ maturity in both cropping seasons. Similarly, there were significant effects of $\mathrm{N}$ rates on dry weight of leaves, weight of biomass at harvest and number of pods per plant up to a maximum of $90 \mathrm{~kg} \mathrm{~N} \mathrm{ha}{ }^{-1}$. P rates showed no significant effect on all characteristics measured. There was an interaction between cropping seasons and $\mathrm{N}$ rates on weight of biomass at $8 \mathrm{WAS}$ and number of pods per plant. It was therefore concluded that application of $\mathrm{N}$ had a significant effect $(\mathrm{P} \leq 0.05)$ on some yield characteristics of sesame in Mubi. P rates up to $45 \mathrm{~kg} \mathrm{ha}^{-1}$ however, had no significant $(\mathrm{P}>$ 0.05 ) effect on phenological and yield characteristics. Further research needs to be conducted on $\mathrm{N}$ and $\mathrm{P}$ rates above 90 and $45 \mathrm{~kg} \mathrm{ha}^{-1}$, respectively, to ascertain effects of optimum rates of $\mathrm{N}$ and $\mathrm{P}$ on sesame phenological and yield characteristics. In addition, the method of $\mathrm{P}$ application in the form of side dressing 2 to 3 WAS should be considered for possible effects.
\end{abstract}

Key words: Sesame, nitrogen rates, phosphorous rates, cropping seasons.

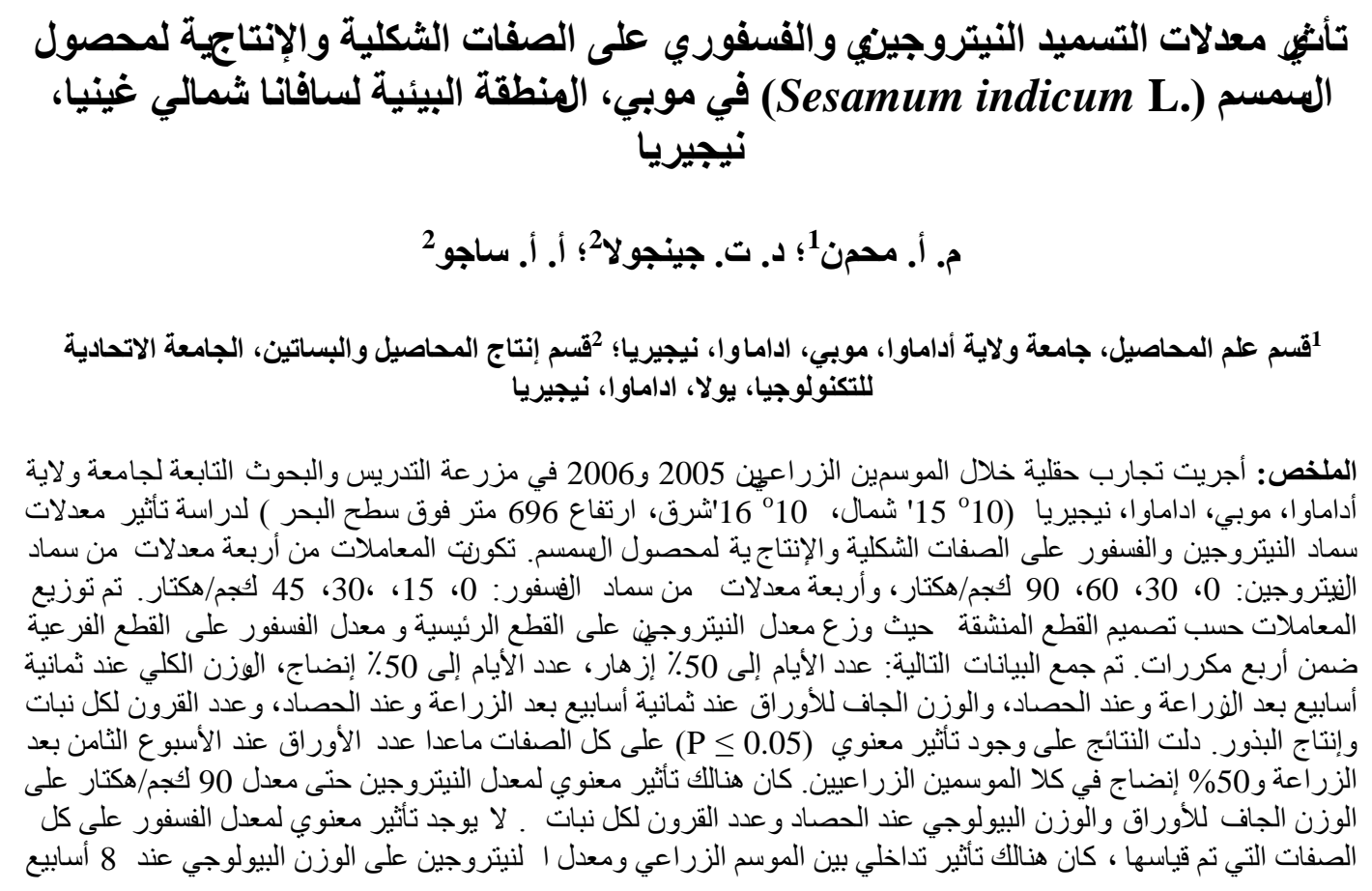




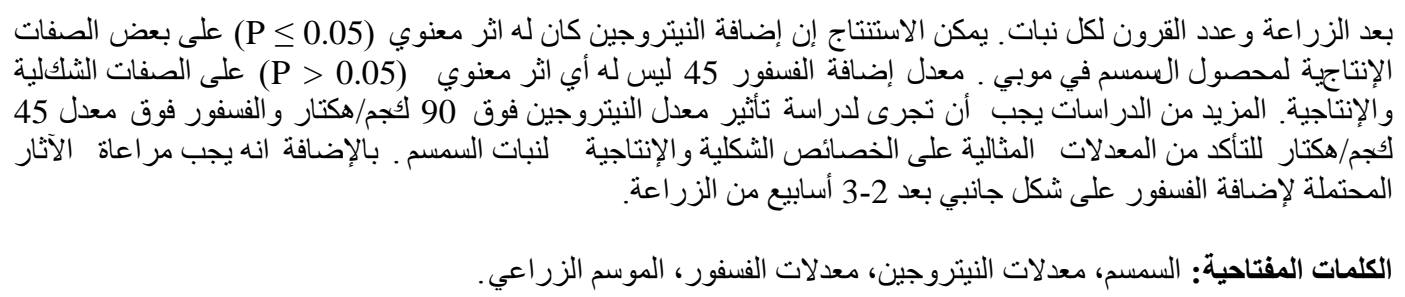

\section{Introduction}

The estimated yield of sesame on farmers' fields in Nigeria which is about $300 \mathrm{~kg} \mathrm{ha}^{-1}$ is too low, compared to 1083 $\mathrm{kg} \mathrm{ha}^{-1}$ in Saudi Arabia, $1960 \mathrm{~kg} \mathrm{ha}^{-1}$ in Venezuela, and $1295 \mathrm{~kg} \mathrm{ha}^{-1}$ in Nigeria (Okpara et al. 2007) under experimental station. The low yield coupled with problems encountered during harvesting sesame have tended to discourage growers, leading to a decline in the total area devoted to its cultivation. In general, the production constraints include poor cultural practices, pests, diseases, weed, poor soil fertility, and poor yield of varieties under cultivation.

Efforts to improve sesame yield becomes pertinent to meet demands, since sesame is gaining significance in Nigerian agriculture because of its importance as a cash crop in the world market. Nigeria's current annual export is valued at about 20 million USD and the country is the primary supplier of sesame seed to the world's largest importer, Japan (Anon, 2002). Sesame seed, popularly called "big treasure in small capsules" is currently ranked as second best to cocoa in terms of export volume and value (Anon, 2004).

Detailed fertilizer studies have indicated that application of nitrogen and phosphorous fertilizers to sesame gives a reasonable chance of increased economic return. According to Olowe and Busari (2000) the number of capsules per plant of sesame increased from 31 to 42 with the application of $90 \mathrm{~kg} \mathrm{~N} \mathrm{ha}^{-1}$ ( from $0 \mathrm{~kg} \mathrm{~N}$ $\left.\mathrm{ha}^{-1}\right)$. Similarly, Malik et al. (2003) reported a significant increase in the number of capsules per plant (97.88) with the application of $80 \mathrm{~kg} \mathrm{~N}^{-1}$. Haggai (2004) reported an increase in the number of pods from 18 to 44 with the application of $90 \mathrm{~kg} \mathrm{~N} \mathrm{ha}^{-1}$ (from $0 \mathrm{~kg} \mathrm{~N} \mathrm{ha}^{-1}$ ). Ahmad et al. (2002) reported increase in yield and yield attributes of sesame with the application of $60 \mathrm{~kg} \mathrm{~N} \mathrm{ha}{ }^{-1}$. Similarly, Olowe and Busari (2000) reported a significant increase in grain yield of sesame from $78.72 \mathrm{~kg} \mathrm{ha}^{-1}$ at $0 \mathrm{~kg} \mathrm{~N} \mathrm{ha}^{-1}$ to $214.89 \mathrm{~kg} \mathrm{ha}^{-1}$ with the application of 60 $\mathrm{kg} \mathrm{N} \mathrm{ha}^{-1}$. Olowe and Busari (2000) further reported grain yield reduction by $38.6 \%$ with increase in $\mathrm{N}$ level to $90 \mathrm{~kg} \mathrm{ha}{ }^{-1}$ obtaining a yield of $132.04 \mathrm{~kg} \mathrm{ha}^{-1}$. In a similar study Malik et al. (2003) reported a significant increase in seed yield $(0.794 \mathrm{t}$ $\mathrm{ha}^{-1}$ ) with the application of $80 \mathrm{~kg} \mathrm{~N} \mathrm{ha}^{-1}$. Haggai (2004) reported an increase in seed yield from $472 \mathrm{~kg} \mathrm{ha}^{-1}$ with $0 \mathrm{~kg} \mathrm{~N} \mathrm{ha}^{-1}$ to $779 \mathrm{~kg} \mathrm{ha}^{-1}$ with $90 \mathrm{~kg} \mathrm{ha}^{-1}$. Haggai (2004) also reported an increase in the number of pods of sesame from 25 at $0 \mathrm{~kg} \mathrm{P}_{2} \mathrm{O}_{5} \mathrm{ha}^{-1}$ to 34 with the application of $50 \mathrm{~kg} \mathrm{P}_{2} \mathrm{O}_{5}$ $\mathrm{ha}^{-1}$. Similarly, Haggai (2004) reported seed yield increased in sesame from 416 $\mathrm{kg} \mathrm{P}_{2} \mathrm{O}_{5}$ ha $^{-1}$ with $0 \mathrm{~kg} \mathrm{P}_{2} \mathrm{O}_{5} \mathrm{ha}^{-1}$ to 851 with the application of $50 \mathrm{~kg} \mathrm{P}_{2} \mathrm{O}_{5} \mathrm{ha}^{-1}$. According to Olowe and Busari (2000) the highest grain yield of $260.93 \mathrm{~kg} \mathrm{ha}^{-1}$ was obtained with the application of $\mathrm{P}$ with $\mathrm{N}$ levels up to $30 \mathrm{~kg} \mathrm{P}_{2} \mathrm{O}_{5} \mathrm{ha}^{-1}$ with $60 \mathrm{~kg} \mathrm{~N}$ $\mathrm{ha}^{-1}$. Increasing $\mathrm{N}$ with $\mathrm{P}$ levels to $90 \mathrm{~kg} \mathrm{~N}$ $\mathrm{ha}^{-1}$ with $60 \mathrm{~kg} \mathrm{P}_{2} \mathrm{O}_{5} \mathrm{ha}^{-1}$ reduced grain yield to $158.15 \mathrm{~kg} \mathrm{ha}^{-1}$. In a similar study, Haggai (2004) reported that number of pods per plant was significantly influenced by interaction of nitrogen and phosphorous, where the highest combination of $\mathrm{N}$ with $\mathrm{P}$, and at $90 \mathrm{~kg} \mathrm{~N}$ with $50 \mathrm{~kg} \mathrm{P}_{2} \mathrm{O}_{5} \mathrm{ha}^{-1}$ gave the highest 
effect. According to Haggai (2004) seed yield was found to be affected with the interaction of $\mathrm{N}$ with $\mathrm{P}$; the highest interaction effect recorded was with the application of $60 \mathrm{~kg} \mathrm{~N}$ with $50 \mathrm{~kg} \mathrm{P}_{2} \mathrm{O}_{5} \mathrm{ha}^{-}$ 1 . Further increase of $\mathrm{N}$ rate to $90 \mathrm{~kg} \mathrm{~N} \mathrm{ha}^{-1}$ at the same $\mathrm{P}$ level decreased seed yield significantly.

The major sesame producing areas in Nigeria are Nasarawa, Jigawa, Benue, Yobe, Kano, Katsina, Kogi, Gombe and Benue State (Anon., 2002). Even though Adamawa State (where Mubi is located) is not among the major producing states, its production is rapidly gaining ground. There is a dearth of information on the fertilizer requirement for sesame in Mubi. Therefore, this research was aimed at validating and if possible adding to the previous findings in other areas, thus providing valuable data for sesame production in Mubi and other regions with similar soil and weather conditions.

\section{Materials and Method}

Field experiments were conducted at the Teaching and Research Farm of the Adamawa State University, Mubi (Latitude $10^{0} 15^{\prime} \mathrm{N}$ and longitude $13^{0} 16^{\prime} \mathrm{E}$, at an altitude of $696 \mathrm{~m}$ above sea level) during the 2005 and 2006 cropping seasons. The experiments were conducted to study the effect of nitrogen $(\mathrm{N})$ and phosphorous $(\mathrm{P})$ rates on some phenological and yield characteristic of sesame. Composite soil samples were collected during the two cropping seasons to determine physicochemical properties of the experimental site. Rainfall data was also collected during this time.

The experiments were conducted on the same site which was previously under cereal cultivation. The land was ploughed and harrowed during both seasons to obtain a fine tilt, there after marked into plots. Total land area used for the experiment was $1142.35 \mathrm{~m}^{2}(15.5 \mathrm{~m} \times 73.7$ $\mathrm{m})$, with a gross plot size of $4.2 \mathrm{~m} \times 3 \mathrm{~m}$, and net plot size of $1.2 \mathrm{~m} \mathrm{x} 1.95 \mathrm{~m}$. Alleyways were created between the replications and between plots, of width $1.0 \mathrm{~m}$ and $0.5 \mathrm{~m}$ respectively.

The treatments consisted of four rates of $\mathrm{N}: 0,30,60$ and $90 \mathrm{~kg} \mathrm{ha}^{-1}$ and four rates of P: $0,15,30$ and $45 \mathrm{~kg} \mathrm{ha}^{-1}$. The treatments in factorial combinations were laid out in a split-plot design and replicated four times. Nitrogen was assigned to main plots and phosphorous to sub-plots. Sesame variety PB-Til no.1 obtained from ADADP was used for the study. The seeds were sowed on July 21, 2005 and July 24, 2006 for the first and second experiments respectively. The sowing was done by seed drilling in rows with a row spacing of 60 $\mathrm{cm}$. The seedlings were later thinned to achieve a $15 \mathrm{~cm}$ spacing between plants after two weeks of emergence as recommended by ADADP (1996). The appropriate $\mathrm{P}$ rate and half of the total amount of $\mathrm{N}$ were added to the soil during field leveling as a pre-plant application while the remaining half of $\mathrm{N}$ was applied as side dressing 3 weeks after sowing. Weeds were controlled manually using hoes at 3,5 and 9 weeks after sowing, and there were no pest problems during the two cropping seasons. After emergence, the following data were collected on some phenological and yield characteristics: days to $50 \%$ flowering, days to $50 \%$ maturity, weight of biomass at 8 WAS and at harvest, dry weight of leaves at 8 WAS and at harvest, number of pods per plant and total seed yield. The data were then subjected to analysis of variance (ANOVA) using the split plot design method of Genstat for windows (Genstat 5 Release 3.2, 1995). Means showing significant F-test were separated using protected Least Significant Difference (LSD) method.

\section{Results}

The results of composite soil samples for the two cropping seasons used in determining the physicochemical 
properties of the experimental sites as well as rainfall data for the two seasons are presented in Table 1.

Tables 2, 3, and 4 show that there were significant effects of cropping seasons on all characteristics measured, except on the number of leaves at 8 WAS and days to $50 \%$ maturity, with the 2006 cropping season having the highest effect on the parameters measured.

Table 1. Soil physicochemical properties and monthly rainfall of the experimental site during the 2005 and 2006 cropping seasons.

\begin{tabular}{|c|c|c|}
\hline Soil properties & 2005 & 2006 \\
\hline Soil pH $\left(\mathrm{H}_{2} \mathrm{O}\right)$ & 5.5 & 5.4 \\
\hline Organic carbon $\left(\mathrm{g} \mathrm{kg}^{-1}\right)$ & 0.45 & 0.42 \\
\hline Organic matter $\left(\mathrm{g} \mathrm{kg}^{-1}\right)$ & 0.74 & 0.76 \\
\hline Total $\mathrm{N}\left(\mathrm{g} \mathrm{kg}^{-1}\right)$ & 0.16 & 0.17 \\
\hline Available $\mathrm{P}\left(\mathrm{mg} \mathrm{kg}^{-1}\right)$ & 7.20 & 7.4 \\
\hline C.E.C $\quad\left(\mathrm{cmol} \mathrm{kg}^{-1}\right)$ & 3.43 & 3.40 \\
\hline Exchangeable $\mathrm{K}\left(\mathrm{cmol} \mathrm{kg}^{-1}\right)$ & 3.04 & 3.10 \\
\hline Exchangeable $\mathrm{Na}\left(\mathrm{cmol} \mathrm{kg}^{-1}\right)$ & 0.98 & 1.02 \\
\hline Exchangeable $\mathrm{Ca}\left(\mathrm{cmol} \mathrm{kg}^{-1}\right)$ & 7.54 & 6.87 \\
\hline Exchangeable $\mathrm{Mg}\left(\mathrm{cmol} \mathrm{kg}^{-1}\right)$ & 2.30 & 2.21 \\
\hline Textural class & Silty loam & Silty loam \\
\hline \multicolumn{3}{|l|}{ Monthly rainfall (mm) } \\
\hline March & 0.00 & 48.50 \\
\hline April & 47.20 & 2.50 \\
\hline May & 75.30 & 92.70 \\
\hline June & 154.70 & 95.60 \\
\hline July & 207.00 & 229.60 \\
\hline August & 329.00 & 216.00 \\
\hline September & 254.70 & 244.00 \\
\hline October & 41.90 & 52.50 \\
\hline Total & 1110.3 & 981.6 \\
\hline Mean & 158.61 & 122.7 \\
\hline
\end{tabular}


Emir. J. Food Agric. 2009. 21 (1): 01-09

http://cfa.uaeu.ac.ae/ejfa.shtml

Table 2. The effect of $\mathbf{N}$ and $P$ on some yield parameters of sesame during the 2005 and 2006 cropping seasons.

\begin{tabular}{|c|c|c|c|}
\hline & $\begin{array}{c}\begin{array}{c}\text { Weight of biomass } \\
\text { eight weeks after sowing } \\
(\mathrm{kg})\end{array} \\
\end{array}$ & $\begin{array}{l}\text { Weight of biomass } \\
\text { at harvest (kg) }\end{array}$ & $\begin{array}{l}\text { Leaves dry } \\
\text { weight (kg) }\end{array}$ \\
\hline \multicolumn{4}{|l|}{ Year } \\
\hline 2005 cropping season & 6.10 & 6.35 & 0.92 \\
\hline 2006 cropping season & 7.28 & 0.77 & 1.25 \\
\hline Level of significance & $*$ & $*$ & $*$ \\
\hline SE & 0.33 & 0.65 & 0.04 \\
\hline \multicolumn{4}{|c|}{ Nitrogen $(\mathrm{N})$ rates $\left(\mathrm{kg} \mathrm{ha}^{-1}\right)$} \\
\hline 0 & 6.07 & 3.77 & 1.36 \\
\hline 30 & 7.02 & 2.64 & 0.90 \\
\hline 60 & 6.32 & 3.08 & 1.10 \\
\hline 90 & 7.37 & 4.76 & 1.01 \\
\hline Level of significance & NS & $*$ & $*$ \\
\hline SE & & 0.61 & 0.10 \\
\hline \multicolumn{4}{|c|}{ Phosphorous (P) rates $\left(\mathrm{kg} \mathrm{ha}^{-1}\right)$} \\
\hline 0 & 6.67 & 3.68 & 1.02 \\
\hline 15 & 6.97 & 3.48 & 1.26 \\
\hline 30 & 6.32 & 3.41 & 1.00 \\
\hline 45 & 6.80 & 3.68 & 1.11 \\
\hline Level of significance & NS & NS & NS \\
\hline
\end{tabular}

Table 3. The effect of $N$ and $P$ on some yield parameters of sesame during the 2005 and 2006 cropping seasons.

\begin{tabular}{|c|c|c|c|}
\hline & $\begin{array}{l}\text { Number of leaves at } \\
\text { eight weeks after sowing }\end{array}$ & $\begin{array}{c}\text { Number of leaves } \\
\text { at harvest }\end{array}$ & $\begin{array}{c}\text { Number of pods } \\
\text { per plant }\end{array}$ \\
\hline \multicolumn{4}{|l|}{ Year } \\
\hline 2005 cropping season & 41.5 & 21.9 & 22.0 \\
\hline 2006 cropping season & 39.5 & 35.3 & 46.5 \\
\hline Level of significance & NS & $*$ & $*$ \\
\hline SE & & 1.92 & 4.7 \\
\hline \multicolumn{4}{|c|}{ Nitrogen $(\mathrm{N})$ rates $\left(\mathrm{kg} \mathrm{ha}^{-1}\right)$} \\
\hline 0 & 38.0 & 33.7 & 34.1 \\
\hline 30 & 36.4 & 28.4 & 32.8 \\
\hline 60 & 36.6 & 29.1 & 26.4 \\
\hline 90 & 51.0 & 23.3 & 43.6 \\
\hline Level of significance & NS & NS & $* *$ \\
\hline & & & 4.1 \\
\hline \multicolumn{4}{|c|}{ Phosphorous (P) rates $\left(\mathrm{kg} \mathrm{ha}^{-\mathbf{1}}\right)$} \\
\hline 0 & 38.2 & 27.2 & 35.6 \\
\hline 15 & 39.9 & 27.2 & 31.9 \\
\hline 30 & 40.7 & 30.8 & 30.9 \\
\hline 45 & 43.2 & 29.3 & 38.5 \\
\hline Level of significance & NS & NS & NS \\
\hline
\end{tabular}


M. A. Muhamman et al.

Table 4. The effect of $N$ and $P$ on some phonological and yield parameters of sesame during the 2005 and 2006 cropping seasons.

\begin{tabular}{lccc}
\hline & $\begin{array}{c}\text { Days to 50\% } \\
\text { flowering }\end{array}$ & $\begin{array}{c}\text { Days to 50\% } \\
\text { maturity }\end{array}$ & $\begin{array}{c}\text { Seed yield } \\
\text { weight (mg/ha) }\end{array}$ \\
\hline Year & 72.40 & & \\
2005 cropping season & 60.33 & 97.67 & 9.5 \\
2006 cropping season & $* *$ & 97.21 & 36.7 \\
Level of significance & 0.38 & $\mathrm{NS}$ & $*$ \\
SE & & & 8.0 \\
Nitrogen (N) rates $\left(\mathbf{k g ~ h a}^{-\mathbf{1}}\right)$ & 66.71 & 97.67 & 19.7 \\
0 & 66.37 & 97.21 & 23.6 \\
30 & 66.79 & 97.50 & 18.3 \\
60 & 65.58 & 97.46 & 30.8 \\
90 & $\mathrm{NS}$ & $\mathrm{NS}$ & $\mathrm{NS}$ \\
Level of significance & & & \\
SE & & & \\
Phosphorous $(\mathbf{P})$ rates $\left(\mathbf{k g ~ h a}^{-\mathbf{1}}\right)$ & 66.42 & 97.63 & 22.5 \\
0 & 66.62 & 97.33 & 19.7 \\
15 & 66.42 & 97.46 & 24.4 \\
30 & 66.00 & 97.42 & 25.8 \\
45 & $\mathrm{NS}$ & $\mathrm{NS}$ & $\mathrm{NS}$ \\
\hline Level of significance & & & \\
\hline
\end{tabular}

NS $=$ Not significant at $5 \%$ level of significance; $*=$ Significance at $5 \%$ level of significance; $* *=$ Highly significant at $1 \%$ level of significance.

There was an interaction effect between seasons and $\mathrm{N}$ rates on weight of biomass at eight weeks after sowing and number of pods per plant (Table 5). However, no interaction effects were observed on other treatments.

Mean values of yield characteristics in 2005 and 2006 cropping seasons are presented in Table 2, 3 and 4. There were no significant effects $(\mathrm{p}>0.05)$ of $\mathrm{N}$ rates on weight of biomass at $8 \mathrm{WAS}$, number of leaves at $8 \mathrm{WAS}$ and at harvest as well as on total seed yield. However, there were significant effects $(\mathrm{p} \leq 0.05)$ of $\mathrm{N}$ rates on weight of biomass at harvest, dry weight of leaves and number of pods per plant, with $90 \mathrm{~kg} \mathrm{~N} \mathrm{Na}^{-1}$ producing the highest effect on weight of biomass at harvest and number of pods per plant, giving the highest values of $4.76 \mathrm{~g}$ and 43.6 respectively.

Mean values for phenological characteristics during the two cropping seasons are presented in Table 4. There were no significant effects $(\mathrm{p}>0.05)$ of $\mathrm{N}$ rates on days to 50 percent flowering and days to 50 percent maturity.

Yield characteristics in the two cropping seasons as shown in Tables 2, 3 and 4 displayed no significant effect ( $p>$ 0.05 ) with $P$ rates on all the characteristics measured. 
Emir. J. Food Agric. 2009. 21 (1): 01-09

http://cfa.uaeu.ac.ae/ejfa.shtml

Table 5. Interaction effect of Season and Nitrogen rates on weight of biomass at eight weeks after sowing and number of pods per plant during the 2005 and 2006 cropping seasons.

\begin{tabular}{lcccc}
\hline & \multicolumn{2}{c}{$\begin{array}{c}\text { Weight of Biomass at } \\
\text { eight weeks after sowing }(\mathbf{k g})\end{array}$} & \multicolumn{2}{c}{$\begin{array}{c}\text { Number of pods } \\
\text { per plant }\end{array}$} \\
\hline Nitrogen rates $\left(\mathbf{k g ~ h a}^{-1}\right)$ & 2005 & 2006 & 2005 & 2006 \\
0 & 0.94 & 2.72 & 24.8 & 43.3 \\
30 & 0.99 & 3.65 & 18.7 & 47.0 \\
60 & 0.93 & 3.42 & 21.8 & 31.0 \\
90 & 1.18 & 6.71 & 22.7 & 64.4 \\
Level of significance & $\mathrm{NS}$ & $*$ & $\mathrm{NS}$ & $* *$ \\
SE & \multicolumn{2}{c}{0.98} & \multicolumn{3}{c}{6.9} \\
\hline NS = Not significant at 5 \% level of significance; *= Significance at 5 \% level of \\
significance; ** = Highly significant at 1 \% level of significance.
\end{tabular}

\section{Discussion}

The significant effect observed on most of the characteristics measured with the cropping seasons might not be the result of variation of the seasons. The amount of rainfall received in 2006 was evenly spread unlike in 2005 when there were erratic showers. This might have been the reason for the interaction of $\mathrm{N}$ rates and the two seasons. Infrequent and erratic showers are typically known to wash away the top soil and available nutrients, thus making them unavailable to plants.

The non-significant effect of $\mathrm{N}$ rates on number of leaves at 8WAS and at harvest in the two cropping seasons might be due to the split application of $\mathrm{N}$, therefore meeting up with the $\mathrm{N}$ requirement. Consequently, differences could not occur between the treatments, therefore affecting weight of biomass at harvest. On the other hand, the nonsignificant effect of $\mathrm{P}$ in the two cropping seasons on number of leaves at 8 WAS and at harvest might have been due to the slow release of $\mathrm{P}$ as well as the low rates of P used.
The significant increase in number of pods per plant up to a maximum of $90 \mathrm{~kg}$ $\mathrm{N} \mathrm{ha}^{-1}$ may have resulted from the amount of $\mathrm{N}$ added. The result was in line with that of Malik et al. (2003) who reported an increase in the number of capsules per plant with increasing $\mathrm{N}$ rates. The nonsignificant effect of $\mathrm{P}$ application on number of pods per plant in the two cropping seasons might be due to the low rates of $\mathrm{P}$ used.

Application of $\mathrm{N}$ on date to 50 percent flowering and on date to 50 percent maturity in the two cropping seasons showed no significant effect which might be due to the life cycle of the plant as well as the day sensitive nature of the plant. Similarly, no effect with $\mathrm{P}$ applications were observed on days leading to 50 percent flowering which may have been due to the day sensitive nature of the plant as well as the life cycle of the plant. An earlier report by Oplinger et al. (1997) supports this finding, in which they indicated that depending on variety sesame, harvesting could occur approximately 90 to 150 days after sowing. 
Similarly, non-significant effect of N on seed yield might be due to the application method and timing. Applications were done in two split doses, first at land preparation and second at 3 WAS which may have been exhausted before the time of seed production. Similarly, the non-significant effect of $\mathrm{P}$ on seed yield and other characteristics measured have been due to the time $\mathrm{P}$ was applied as well as the rates used. Thus, the amount of $\mathrm{P}$ needed may be higher than what was used in the study.

\section{Conclusion and Recommendation}

From the results, it can be concluded that $\mathrm{N}$ application had a significant effect on some yield characteristics of sesame such as dry weight of leaves, weight of biomass at harvest and number of pods per plant up to a maximum of $90 \mathrm{~kg} \mathrm{~N} \mathrm{ha}^{-1}$. And $P$ rates up to a maximum of $45 \mathrm{~kg} \mathrm{ha}^{-1}$ showed no significant effect on all the characteristics measured. There was however an interaction between cropping seasons and $\mathrm{N}$ rates, on weight of biomass at 8 WAS and number of pods per plant due to rainfall effects. Therefore, further research on $\mathrm{N}$ and $\mathrm{P}$ rates above 90 and 45 $\mathrm{kg} \mathrm{ha} \mathrm{h}^{-1}$, and application timing is recommended. Also, the method of $P$ application in the form of side dressing, 2 to 3 WAS should be considered for future research.

\section{References}

Anomymous. 2002. Over view of the Nigerian Sesame Industry. Prepared for the United States Agency for International Development (USAID)/Nigeria. Chemonic International Inc. Washington D.C., USA. pp. 34.

Anonymous. 2004. Nigeria targets N 1.8 B annually from sesame export. Daily Independent Newsletter Limited, Lagos, Nigeria.
Okpara, D. A., C. O Muoneke and T. O. Ojikpong. 2007. Effects of nitrogen and phosphorous fertilizer rates on the growth and yield of Sesame (Sesamum indicum L.) in the Southeastern Rainforest Belt of Nigeria. Nigerian Agricultural Journal. 38:1-811.

Adamawa State Agricultural Development Programme. 1996. Benniseed In: Crop production recommendation for Adamawa State. ADADP, Yola, Nigeria. pp 46- 47.

Ahmad R., T. Mahmood, M. Farrukh Saleem and S. Ahmad. 2002. Comparative performance of two Sesame (Sesamum indicum L.) varieties under different row Spacing. Asian Journal of plant Sciences. Volume 1 number 5:546-547.

Genstat 5 Release 3.2. 1995. Lawes Agricultural Trust (Rothamsted experimental Station) AFRC Institude of Arable crops Research, Herpenden, Herdfordshire.

Haggai P. T. 2004. Effects of Nitrogen and Phosphorous Application on Yield Attributes and Seed Yield of Sesame (Sesamum indicum L.) in Northern Guinea Savanna of Nigeria. Proceedings of $38^{\text {th }}$ Annual Conference of the Agricultural Society of Nigeria (ASN). Lafiya, Nasarawa State, Nigeria. pp 150157.

Malik, A M., M. F. Saleem, M. A. Cheema and S. Ahmed. 2003. Influence of different nitrogen levels on productivity of Sesame (Sesamum indicum L.) under varying planting patterns. International Journal of Agriculture and Biology. 4:490-2.

Olowe V. I. O. and L. D. Busari. 2000. Response of Sesame (Sesamum indicum L.) to Nitrogen and 
Emir. J. Food Agric. 2009. 21 (1): 01-09

http://cfa.uaeu.ac.ae/ejfa.shtml

Phosphorous Application in Southern

Sesame, Alternative Field Crop Guinea Savanna of Nigeria. Tropical Manual. University Wisconsin Oilseed Journal. pp. 30-37.

Extension, Cooperative Extension. University of Minnesota: Center for

Oplinger E. S., D. H. Putnam, A. R. Kamiski, C. V. Hanson, E. A. Oelke, E. E. Schulte, and J. D. Doll. 1997. alternative plant and animal products and Minnesota Extension Services. 